\title{
WORK PATTERNS AND A TENDENCY AMONG POLISH NURSES TO LEAVE THEIR JOB
}

\author{
Dorota Kilańska ${ }^{1}$, Aleksandra Gaworska-Krzemińska ${ }^{2,3}$, Agnieszka Karolczak ${ }^{1}$, \\ Piotr Szynkiewicz ${ }^{4}$, Małgorzata Greber ${ }^{1}$ \\ ${ }^{1}$ Medical University of Lodz, Łódź, Poland \\ Faculty of Health Sciences with the Division of Nursing and Midwifery, \\ Department of Social Nursing and Management in Nursing, Department of Health System Development \\ ${ }^{2}$ Medical University of Gdansk, Gdańsk, Poland \\ Faculty of Health Sciences, Department of Nursing \\ ${ }^{3}$ Pomeranian University in Słupsk, Słupsk, Poland \\ Faculty of Health Sciences, Department of Nursing \\ ${ }^{4}$ Academy of Management, Sopot, Poland
}

\begin{abstract}
Background: Work patterns are important factors in employees' decisions to change their job or leave their profession. The majority of nurses in Poland are women who play other social roles besides work. For this reason, satisfaction with their work patterns including input into work schedules, has a particularly significant impact on considering the idea of quitting their job. Material and Methods: The study was conducted in 2008-2011 in 8 out of 10 higher education institutions which train nurses. Data obtained from 1045 questionnaires collected from a total of 1049 respondents from 3 randomly selected higher education institutions was used in this research paper. The relationship between the qualitative features and dichotomus quality features under examination was assessed using univariate and multivariate logistic regression models. Results: The results of the univariate logistic regression indicate that the risk of quitting increases to the highest extent with a mixed work pattern; it is lower for $12 / 24 \mathrm{~h}$, and slightly lower for 2 day/night shifts. Conclusions: A pattern with a single day shift was adopted as the reference level to reduce the risk of Polish nurses' quitting their job. Med Pr. 2018;70(2):145-53
\end{abstract}

Key words: employment, personnel turnover, staffing and scheduling, rotating shift work, nurses, intention to leave

Corresponding author: Dorota Kilańska, Medical University of Lodz, Faculty of Health Sciences with the Division of Nursing and Midwifery, Department of Social and Management in Nursing, Department of Health System Development, Jaracza 63, 90-251 Łódź, Poland, e-mail: dorota.kilanska@umed.lodz.pl

Received: December 18, 2017, accepted: July 19, 2018

\section{INTRODUCTION}

Nurses are responsible for managing the quality of health care provided to patients [1]. The nurse's role involves immediate detection and intervention when patients' clinical conditions change. There are research studies confirming that during a $12-\mathrm{h}$ shift nurses visit 157 locations and some repeatedly perform numerous minor activities that fundamentally support therapeutic processes. The authors of the research confirm that nurses had at least 2 occurrences of a heavy traffic pattern ( 8 or more trips to the same area on a shift) [2]. Their commitment and efficiency influence the safety and satisfaction of patients [3]. Nurses who often work overtime or without proper rest are more susceptible to higher absenteeism and deterioration in their health status [4]. The more hours spent at work, the more prominent certain factors become, including an increased risk of diseases, conflicts, dissatisfaction with work, and leaving the profession; the effectiveness of nursing interventions is also negatively affected. According to the Royal College of Nursing, $22 \%$ of nurses would change their job if they were offered more favorable working conditions $[5,6]$.

The costs of nursing turnover can be high (over USD 10000 per registered nurse turnover), and there is a potential for adverse impact on the hospital environment $[7,8]$. The turnover cost represents more than $5 \%$ of the hospital budget. The loss of staff also affects the quality of care [9]. The projected shortage of nurses in Poland in 2020 is over 60 000, which corresponds to one-third of the nurses who were working in 2010 [10,11]. Creating a positive work environment has become the priority for many organizations. The International Council of Nurses (ICN) describes a Positive Practice Environment (PPE) as a set of financial and nonfinancial factors that encourage nurses to apply for 
specific jobs, motivate good-quality work, encourage them to meet their employer's requirements, and contribute to their work-life balance, while discouraging them from leaving the organization. The work environment also comprises a system of incentives relevant to an individual $[6,12]$. Work patterns form an elements of this environment, which may also account for the nurses' intention to quit [13].

Work patterns encompass working time, breaks, and pace of work [14]. Satisfaction with a given work pattern is understood as an opportunity to influence the work schedule, holiday dates, the use of annual leave, and the absence of obligatory overtime work. The Polish Labour Code lists the following work patterns: a basic work pattern, an equivalent working-time pattern, a continuous work pattern, an intermittent working-time pattern, a task-based working-time pattern, a reduced working-week pattern, and a weekend working-time pattern [14]. The basic number of working hours is $8 \mathrm{~h} /$ day. In the equivalent working-time pattern, working hours may be extended to $12 \mathrm{~h}$, and in specific types of work to $16 \mathrm{~h}$ or $24 \mathrm{~h}$. It is permissible to extend the working hours to an average of $43 \mathrm{~h} /$ week [14]. In accordance with Article 93.1 of the Act on Health Service Facilities, at any given time, the working hours of an employee at such a facility cannot exceed either $7 \mathrm{~h} 35 \mathrm{~min} /$ day or an average of $37 \mathrm{~h} 55 \mathrm{~min} /$ week, in an average 5-day working week. Consequently, the working hours of health professionals in Poland are 25 min shorter per day than in other professions. At the same time, however, Article 94.1 of the Labour Code further defines situations in which working hours can be extended to $12 \mathrm{~h} /$ day, if this is justified by the type or organization of work [14]. In inpatient care at hospitals, this option is employed almost standardly, with hospital nurses working mainly in 2 shifts (day and night) of $12 \mathrm{~h}$ each.

\section{Aim of research}

The aim of this study was to assess the relationship between Polish nurses' work patterns (and some of their features) and the risk of quitting. The main research question was thus whether, and to what extent, work patterns - including the work schedules matching nurses' personal preferences - affected the nurses' decision to quit their job.

\section{MATERIAL AND METHODS}

The study was conducted using a quantitative method: a diagnostic survey with a questionnaire. The relation- ship between the 2 quality characteristics was evaluated using a $\chi^{2}$ test of independence or a $\chi^{2}$ test of independence with the Yates correction. The relationships between the qualitative characteristics and the dichotomous quality characteristics were evaluated with the use of univariate and multivariate logistic regression models. The level of significance was determined at $\mathrm{p} \leq 0.05$.

The research tool was the PPE questionnaire [8] developed by the UK Royal College of Nursing (RCN). The tool was made available by the RCN for free to be used in the research. The tool was validated and approved by the Department of Social and Management at the Medical University of Lodz in cooperation with certified translators in 2007. The questionnaire was translated, validated, and adapted to the needs and conditions of the study in Poland. The study was conducted in 2008-2011. This analysis involves the results of the survey on a group of 3 (out of 10) randomly selected public medical schools that offer Master's courses in nursing: the Medical University of Lodz, the Pomeranian Medical University in Szczecin and the Medical University of Warsaw. Nurses attending such courses work in the profession while complementing their education to the Master of Science (MSc) level in part-time programs. The respondents were assured of anonymity and of the voluntary nature of their participation in the research. The researchers obtained 1049 questionnaires, with a $90 \%$ response rate. Out of the $1049 \mathrm{ob}$ tained questionnaires, 1045 qualified for the statistical analysis. This allowed the responses to be representative.

Assessing the risk of nurses turnover involved analyzing the variables of time, work pattern, and remuneration. This study is the continuation of the research published in an article by Kilańska et al. [15], due to that fact, this article is focused only on the aspect of work patterns.

In order to assess satisfaction with work patterns, the respondents were asked which shift pattern was adopted in their main place of work. Nurses selected one of the following answers: "day shifts only" (further specified as morning shifts, afternoon shifts, and 12-h shifts during the day), "day and night shifts" (referred to in the analysis as mixed shifts), or "night shifts only;" this last option was included because of the reference to the research conducted in the UK, where there was typically such a shift choice. In Poland, this option is rarely found. The survey also included questions about satisfaction with the selected work pattern and prefer- 
ences in relation to work in a different shift system, if there was such an option at the current place of employment. Questions were also asked about the length of shifts, with the following choice of answers: "7 $\mathrm{h}$ 35 min," " 8 h," " 12 h," and "other;" in the last case, respondents were asked to specify the shift length. The nurses were also asked about their preferences regarding shift duration and how the shift was planned. They were further asked to describe their breaks and working hours. Answers were given on a Likert scale. For the purpose of this analysis, such responses were aggregated in 2 groups: "agree/strongly agree" and "disagree/ strongly disagree.”

The use of multivariate logistical regression for statistically significant variables in the univariate model allowed for the selection of the most important features that had a statistically significant impact on the decision to quit.

\section{RESULTS}

\section{Characteristics of respondents}

The study involved 1045 nurses with secondary education. Almost every second nurse was a graduate of a medical high school for nurses, and over $45 \%$ of nurses graduated from post-secondary nursing schools. All the respondents were working as nurses while attending an MSc course in nursing at the same time. The average age of the respondents was 43.

The collected data leads to the conclusion that almost $70 \%$ of the respondents were older than 35 (therein: 53\% were aged $35-44$ and almost $15 \%$ aged $45-54$ ), but only $12.7 \%$ of the nurses taking part in the study were younger than 30 years old. It should be added that such a division reflects the real age structure of nurses in Poland.

Among the nurses who specified their place of employment in the questionnaire, more than $40 \%$ were employed in other non-listed facilities. The largest group consisted of nurses who worked at intensive care units (almost every fifth nurse). Every 10th nurse worked in a geriatric ward, and nearly $10 \%$ worked in primary care. Nurses who worked in community health centers accounted for $20.9 \%$ of the respondents (more than every fifth nurse). Almost 10\% of the nurses took care of patients with long-term sickness. Such a large number of community health nurses may indicate increasing requirements to contracting nursing services, also as independent subjects not related to public health service. More than $8 \%$ of the respondents worked in the pediatric departments, and $6.3 \%$ - in the wards where gynecological and obstetric care is provided.

The employers of more than a half of the nurses (58.3\%) respected their wishes as to when and how they wanted to work whereas $40 \%$ of the respondents could not use this privilege. Although the vast majority of nurses $(80 \%)$ were informed of changes in their work schedules, almost 1 in 5 (19.6\%), in the absence of such information, experienced difficulties in planning their private lives. The research showed that $35 \%$ of the nurses worked in excess of their contracted hours, and the same number of nurses $(35.3 \%)$ were dissatisfied with their inability to plan holidays. Nearly one-fourth of the surveyed nurses $(24.8 \%)$ indicated that the number of hours spent at work did not suit them, and more than a half (55.2\%) were not satisfied with their options to choose the shift length (Table 1).

Table 1. The work pattern satisfaction in the study conducted between 2008-2011 on a sample of Polish nurses with the secondary level of education $(\mathrm{N}=1045)$

\begin{tabular}{|c|c|c|}
\hline \multirow{2}{*}{ Variable } & \multicolumn{2}{|c|}{$\begin{array}{c}\text { Prevalence rate ratio } \\
{[\%]}\end{array}$} \\
\hline & $\begin{array}{l}\text { disagree/strongly } \\
\text { disagree }\end{array}$ & $\begin{array}{c}\text { agree/strongly } \\
\text { agree }\end{array}$ \\
\hline $\begin{array}{l}\text { Generally able to get the off-duty/time-off } \\
\text { when they (nurses) want }(\mathrm{N}=950)\end{array}$ & 41.2 & 58.8 \\
\hline $\begin{array}{l}\text { Satisfaction with the length of time } \\
\text { work schedule is planned } \\
\text { in advance }(\mathrm{N}=960)\end{array}$ & 11.5 & 88.5 \\
\hline $\begin{array}{l}\text { Find it hard to plan life outside of work } \\
\text { because their working hours vary } \\
\text { so much }(\mathrm{N}=957)\end{array}$ & 34.0 & 66.0 \\
\hline $\begin{array}{l}\text { Employer respects wishes about } \\
\text { when and how nurses wish to } \\
\text { work }(\mathrm{N}=963)\end{array}$ & 41.7 & 58.3 \\
\hline $\begin{array}{l}\text { Given sufficient notice of changes } \\
\text { to the off-duty rota }(\mathrm{N}=951)\end{array}$ & 19.6 & 80.4 \\
\hline $\begin{array}{l}\text { Frequently work in excess of contracted } \\
\text { hours }(\mathrm{N}=945)\end{array}$ & 35.0 & 65.0 \\
\hline $\begin{array}{l}\text { Satisfaction with the choice given over } \\
\text { the length of shifts work }(\mathrm{N}=927)\end{array}$ & 55.2 & 44.8 \\
\hline $\begin{array}{l}\text { Satisfaction with the level of input } \\
\text { in planning own off-duty/time off } \\
(\mathrm{N}=937)\end{array}$ & 35.3 & 64.7 \\
\hline $\begin{array}{l}\text { Generally get to work the shifts/times } \\
\text { that they want }(\mathrm{N}=944)\end{array}$ & 33.7 & 66.3 \\
\hline $\begin{array}{l}\text { The amount of unsocial hours they } \\
\text { work suits them well }(\mathrm{N}=966)\end{array}$ & 24.8 & 65.2 \\
\hline
\end{tabular}

Bolded values - statistically significant. 


\section{Work pattern and the risk of quitting}

An odds ratio is the ratio of the probability of a given occurrence (in this case, the chance of quitting the job) in the study group to the probability of the same occurrence in the reference group. The reference group in this study included those working continuously in one shift lasting an average of $7 \mathrm{~h} 35 \mathrm{~min} /$ day. Thus, e.g., for the first analyzed variable - "being generally able to take time off when they want" - nurses who did not have such an opportunity had a risk of quitting in almost a half greater number than the nurses who had this opportunity. This relationship was identified as statistically significant ( $p=0.004577)$.

In the univariate analysis, the chance of quitting turned out to be statistically significant if:

the work schedule was not planned in advance ( $\mathrm{p}=$ 0.023555),

- the employer did not respect the nurses' wishes regarding when and how they worked $(\mathrm{p}=0.004048)$,

- the nurses were not informed of changes in their schedule ( $p=0.001676)$,

they were not satisfied with the choice of work shift length $(\mathrm{p}=0.000012)$,

- they were not satisfied with the possibility of taking days off $(p=0.000043)$,

a they were not satisfied with the ability to work in suggested shifts $(p=0.003168)$,

the number of working hours per day was not in line with their expectations $(\mathrm{p}=0.000000)$.

In the case of the "working time" variable, the risk of quitting by the nurses working the $12 / 24 \mathrm{~h}$ pattern $(\mathrm{p}=0.010578)$ was almost twice as high as the risk in the group of nurses working 1 shift (7 h $35 \mathrm{~min}$ ). A 3 times greater risk of quitting was found for work in a mixed system - i.e., with varying shift duration and type $(\mathrm{p}=0.016669)$ (Table 2).

The desire to quit, as expressed by the nurses working both day and night shifts, was slightly more frequent than among those working day shifts only. However, this was not a statistically significant factor. The duration of the shifts was statistically significant. The nurses working a 12 -h system $(\mathrm{p}<0.05)$ or a different (mixed) system of shifts $(\mathrm{p}<0.05)$ declared their willingness to leave the job much more frequently than others. In the case of the salary variable, the nurses who stated that their current remuneration did not match the scope of their job more frequently considered quitting than nurses who felt that their salary was adequate; this was not a statistically significant relationship.

The analysis based on a multivariate regression model showed that "work in a mixed pattern" - i.e., working day and night shifts in a 12/24 h system - had the greatest influence on desire to quit (Table 3 ).

\section{DISCUSSION}

\section{Flexibility with respect to working time}

Being able to choose the work pattern may affect the assessment of the attractiveness of work. In the 2005 survey of nurses in the UK, different patterns of work were considered. Many nurses worked part-time: half-time work was available to $80 \%$ of nurses, this number being $7 \%$ lower than in 2000. Satisfaction with this working pattern slightly improved [12]. A very different situation can be observed among Polish nurses, to whom the option of part-time work is available only in $29.7 \%$ of cases, and more than 1 in $5(22.7 \%)$ are satisfied with it. Polish nurses may appreciate the opportunity to work part-time, as it allows them to, e.g., take care for their aging parents. Nowadays, nurses are working in more than 1 place at the same time [16].

In the general opinion of the researchers studying this issue, working between $34-38 \mathrm{~h}$ /week for no more than $8 \mathrm{~h} /$ day is the most favorable type of shift work. Shifts should consistently start at 7:00 a.m., 3:00 p.m., and 9:00 p.m. During the shift cycle, employees should be able to spend $40 \%$ of the time between shifts in any way they want. Reports from studies conducted on this topic also mention certain forms of compensation for the inconvenience associated with shift work, such as reduction of work on the night shift, reduction of working time (the length of shifts and weekly working time), longer breaks between shifts, and longer rest periods. The value of being able to nap at work, where possible, is emphasized [17]. Monitoring the health of shift workers and properly compensating them for night shifts are also said to be important factors. This mostly pertains to female nurses who still constitute an overwhelming majority in the nursing profession. Night shift work correlates with abnormal menstrual cycles, decreased fertility rates, more frequent miscarriages, and abnormal fetus development. Night shift nurses may also be at a higher risk of developing breast cancer [18]

\section{Working night shifts only}

In the UK, in addition to nurses employed directly by hospitals, there are also nurses employed by agencies. The shifts they are contracted for depend on the needs of the hospital. In this group, 19\% of nurses worked night shifts in 2000 and 2005. Significantly more of them were employed on night and day shifts. Almost three-quarters of the nurses $(72 \%)$ who work shifts in the UK are 
Table 2. Work and turnover risk - univariate logistic regression in the study conducted in 2008-2011 on a sample of Polish nurses with the secondary level education $(\mathrm{N}=1045)$

\begin{tabular}{|c|c|c|c|c|}
\hline \multicolumn{2}{|r|}{ Feature } & \multicolumn{3}{|c|}{ Leave their job } \\
\hline \multicolumn{5}{|c|}{ Generally able to get the off-duty/time-off when they (nurses) want } \\
\hline no & & 1.00 & \multicolumn{2}{|c|}{ ref. } \\
\hline \multicolumn{5}{|c|}{ Satisfaction with the length of time work schedule is planned in advance } \\
\hline no & & 1.00 & \multicolumn{2}{|c|}{ ref. } \\
\hline \multicolumn{5}{|c|}{ Finding it hard to plan life outside of work because their working hours vary so much } \\
\hline yes & & 0.79 & $0.57-1.08$ & 0.144689 \\
\hline no & & 1.00 & \multicolumn{2}{|c|}{ ref. } \\
\hline \multicolumn{5}{|c|}{ Given sufficient notice of changes to the off-duty rota } \\
\hline yes & & 0.56 & $0.39-0.80$ & 0.001676 \\
\hline no & & 1.00 & \multicolumn{2}{|c|}{ ref. } \\
\hline \multicolumn{5}{|c|}{ Frequently work in excess of contracted hours } \\
\hline yes & & 0.90 & $0.66-1.25$ & 0.540554 \\
\hline no & & 1.00 & \multicolumn{2}{|c|}{ ref. } \\
\hline \multicolumn{5}{|c|}{ Satisfaction with the choice given over the length of shifts work } \\
\hline yes & & 0.48 & $0.34-0.66$ & 0.000012 \\
\hline no & & 1.00 & \multicolumn{2}{|c|}{ ref. } \\
\hline no & & 1.00 & \multicolumn{2}{|c|}{ ref. } \\
\hline \multicolumn{5}{|c|}{ The amount of unsocial hours they work suits them well } \\
\hline yes & & 0.37 & $0.27-0.51$ & 0.000000 \\
\hline no & & 1.00 & \multicolumn{2}{|c|}{ ref. } \\
\hline \multicolumn{5}{|c|}{ Current grade/pay-band to be appropriate given the role and responsibilities } \\
\hline yes & & 1.67 & $0.91-3.07$ & 0.099838 \\
\hline no & & 1.00 & \multicolumn{2}{|c|}{ ref. } \\
\hline \multicolumn{5}{|c|}{ Shift patterns at work } \\
\hline day and night & & 1.38 & $0.97-1.97$ & 0.072207 \\
\hline day & & 1.00 & & \\
\hline Working time & & & & \\
\hline other & & 3.01 & $1.22-7.45$ & 0.016669 \\
\hline $12 \mathrm{~h}$ & & 1.71 & $1.13-2.57$ & 0.010578 \\
\hline $8 \mathrm{~h}$ & & 1.13 & $0.53-2.89$ & 0.750781 \\
\hline $7 \mathrm{~h} 35 \mathrm{~min}$ & & 1.00 & & \\
\hline
\end{tabular}


Table 3. Work and turnover risk - multivariate logistic regression in the study conducted in 2008-2011 on a sample of Polish nurses with the secondary level of education $(\mathrm{N}=1045)$

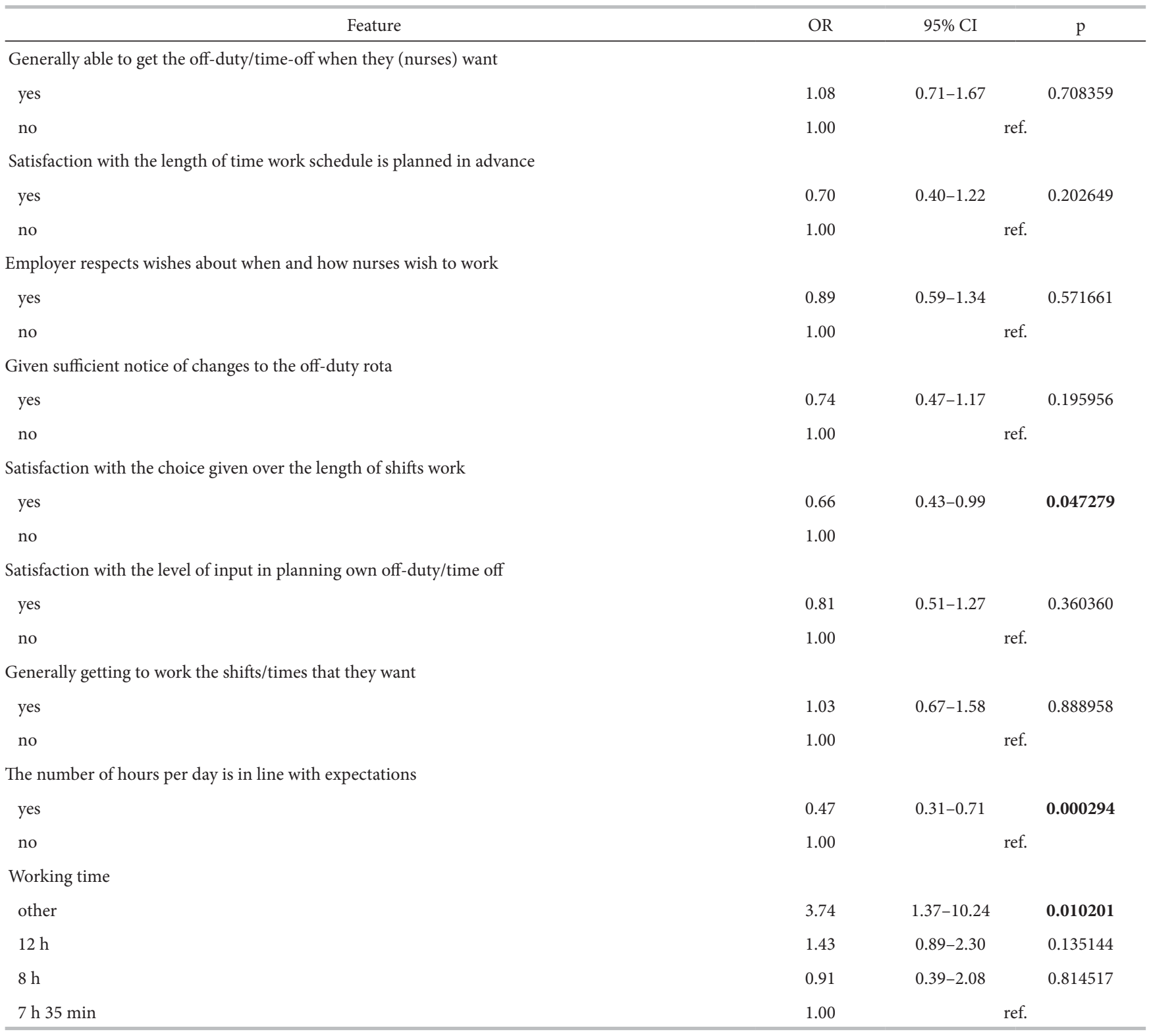

ref. - reference group.

Bolded values - statistically significant.

satisfied with their work pattern; in Poland, less than a half $(44.7 \%)$ are satisfied. The British nurses who only work day or night shifts are generally satisfied with their work pattern ( $85 \%$ of those on day shifts only and $82 \%$ of those on night shifts only). On the other hand, $62 \%$ of the nurses working in the mixed system (day and night shifts) are satisfied with the work pattern [8]. In Poland, there is generally no possibility to work only at night. The $57.8 \%$ of the Polish nurses whose work pattern includes night shifts indicate this mixed pattern of work to be the most unsatisfactory.

\section{Possibility of job sharing}

A possibility of job sharing with other employees is another work pattern may serve as an incentive. It involves, e.g., 2 nurses covering 1 job. The nurses determine the manner and time of work within the contracted time. This work pattern is used by $44 \%$ of nurses in the UK, though by 2006 , their number had decreased by $10 \%$ as compared to the 2000 study [8]. In Poland, 16.3\% of nurses indicated they worked such a pattern; satisfaction with this pattern was reported by $38.9 \%$ of that group [16]. 
On some days, Polish nurses work a short shift of $2 \mathrm{~h}$ or $4 \mathrm{~h}$ on account of the need to work a certain number of contracted hours in a given period (16 weeks or 4 months) under the provisions of the Labour Code. This situation also strongly disrupts the planning of family life [14].

\section{Participation in choosing the work schedule}

Another aspect of work patterns that may encourage nurses to stay in their profession is the option of adjusting their work schedules. In the UK, involving employees in the planning of schedules is increasingly popular. The results of the research conducted in the UK in 2005 indicate a 7\% increase in nurses' involvement in choosing their work schedule as compared to 2000 (the 2005 value was 42\%) [8]. In this study, it has been demonstrated that, in our group of nurses, only 1 in 4 (25.4\%) could choose his or her schedule. For more than a half $(52.4 \%)$ of the Polish nurses, the current solution is not satisfactory [19].

\section{Work and rest}

Performing the professional role of a nurse requires constant and full availability, as well as physical and mental fitness [20]. Due to the intensive nature of the work and significant overtime, rest is very important in a nurse's job. Studies show that even a 30-min nap has a positive effect on an employee's condition and performance. The recommended night-shift nap time is a max. $45 \mathrm{~min}$ long. This does not interfere with the ability to react quickly when the need arises [19]. The research indicates that a lack of rest may lead to professional burnout. Symptoms of professional burnout observed among nurses include fatigue and exhaustion, pain, desire to stay on a sick leave, and irritability. This situation not only reduces the quality of work, but it is also unfavorable to employers [21]. In this study, more than 1 in 4 nurses (28.24\%) were both not able to rest at work and not satisfied with their job. In Poland, nurses do not automatically have the right to take a nap during their shifts.

\section{Work pattern and accident rate}

An 8-h work pattern starting in the morning is the least onerous for nurses. Our results indicate that, after $7 \mathrm{~h}$, the level of fatigue increases, as does the risk of sudden death at work and the relative accident risk index [20,22]. An increase in the number of accidents at work is observed when the number of hours per week is increased. Working 12-h shifts and frequent long-distance commuting may result in a lack of sleep for 18 consecutive hours. According to the US Army study, staying awake for $17 \mathrm{~h}$ is a functional equivalent of $0.05 \%$ blood alcohol concentration (BAC), while remaining awake for $24 \mathrm{~h}$ is equivalent to $0.10 \% \mathrm{BAC}[1,23]$. The type of shift is important. During night shifts, the risk of accidents increases above that of day shifts. Working for 4 consecutive nights results in the risk of accidents at work being 1.4 times higher than the risk during the first night. When weekly working hours exceed $40 \mathrm{~h}$, workers report intensifying back pains, increasing fatigue and sleepiness, digestive ailments, and disease [24,25]. Numerous studies conducted in Poland also provide results confirming these facts [26].

\section{Nurses' health and work systems}

The maximum working time specified in Article 93.1. of the Labour Code applied to less than one quarter of all nurses $(23.3 \%)$. Only $6.7 \%$ of nurses worked under the 8 -h system, while the majority $(67.2 \%)$ worked under a 12-h system of shifts, which was the least beneficial system to health and quality of work. Most of the surveyed nurses (91\%) worked day and night shifts (the mixed system). The inability to select the type of shifts led to dissatisfaction with the system of work in certain groups of nurses. This is demonstrated by this study: nurses' satisfaction depends on the shift. The greatest dissatisfaction with the choice of a shift (55.3\%) occurred among the nurses working night and day shifts (57.8\%). Almost a half of the nurses (49.4\%) were also dissatisfied with working a day shift only, and the relationship between these characteristics proved to be statistically significant $(\mathrm{p}=0.028)$. In the UK study, $15 \%$ of the nurses surveyed in 2000 worked night shifts, while $41 \%$ were employed in the so-called internal rotation, working day and night shifts. However, another study conducted in 2005 indicated that the number of nurses working the night shift decreased $(10 \%)$ while the number of nurses working on internal rotation increased to $60 \%$. The vast majority of the UK nurses worked 7.5-8 h, which resulted from generally accepted work patterns in that country, but also from the concern of the management for work-life balance, patient and employee safety, and work efficiency [8]. This phenomenon was not seen in Polish studies.

\section{Age of nurses and work system flexibility}

In the study group, satisfaction with the work pattern was more often declared by nurses over the age of 40 than by younger nurses. Lipińska's studies also indicate that, the older the nurses, the greater job satisfaction 
they report [27]. This data points to the problem of reconciling private life while also remaining at the employer's disposal. In Poland, one-third of graduating nurses [28] do not apply for a license to practise the profession which may be related to their negative perception of the work environment. Unsatisfactory work patterns - including irregular hours of work and 12-h shifts - are also a factor accounting for professional burnout [29].

\section{CONCLUSIONS}

Polish nurses are given less opportunity to participate in planning their work schedules and have more unpredictable work patterns than their colleagues in the UK. The risk of Polish nurses quitting increases in the case of mixed shifts (both night and day) and 12-h shifts. Polish nurses are not satisfied with their inability to influence the duration of their shifts. Work patterns chosen solely by the employer do not allow for work-life balance among the Polish nurses and leads to a significant disruption of their private lives.

\section{ACKNOWLEDGMENTS}

The authors thank Susan Williams and Sheelegh Brewer from the RCN in the UK for help in obtaining the tools. Members of the Polish Nurses Association (PNA) (Bożena Gorzkowicz, Małgorzata Lewandowska, Zofia Sienkiewicz ) - for their help with testing and Prof. Wojciech Bielecki - for the input regarding statistical results. Special thanks to Mariola Bartusek and Elżbieta Mielczarek-Pankiewicz for helping validate and translate the Positive Practice Environment questionnaire.

\section{REFERENCES}

1. Benner P, Sheets V, Uris P, Malloch K, Schwed K, Jamison D. Individual, practice, and system causes of errors in nursing: A taxonomy. J Nurs Adm. 2002;32(10):509-23, https://doi. org/10.1097/00005110-200210000-00006.

2. Potter P, Wolf L, Boxerman S, Grayson D, Sledge J, Dunagan $\mathrm{C}$, et al. An analysis of nurses' cognitive work: A new perspective for understanding medical errors. In: Henriksen K, Battles JB, Marks ES, Levin D I, editors. Advances in patient safety: From research to implementation. Volume 1: Research findings. Rockville: Agency for Healthcare Research and Quality; 2005.

3. Drenkard K. The business case for Magnet. J Nurs Adm. 2011;42(1):21-7.

4. Sheward L, Hagen S, Macleod M, Ball J. The relationship between UK hospital nurse staffing and emotional exhaus- tion and job dissatisfaction. J Nurs Manag. 2005;13:51-60, https://doi.org/10.1111/j.1365-2834.2004.00460.x.

5. Royal College of Nursing. Working well: A call to employers: A summary of the RCN Working well survey into the wellbeing and working lives of nurses. London: The College; 2000.

6. Bauman A. Positive practice environments: Quality workplaces, quality patient care. Information and action tool kit. Geneva: International Council of Nurses; 2008.

7. Jones CB. Staff nurse turnover costs: Part II, Measurements and results. J Nurs Manag. 1990;20(5):27-32, https://doi. org/10.1097/00005110-199005000-00008.

8. Royal College of Nursing. At breaking point? A survey of the wellbeing and working lives of nurses in 2005. London: The College; 2006.

9. Waldman JD, Kelly F, Arora S, Smith HL. The shocking cost of turnover in health care. Health Care Manage Rev. 2004;29(1): 2-7, https://doi.org/10.1097/00004010-200401000-00002.

10. Naczelna Izba Pielęgniarek i Położnych. Wstępna ocena zasobów kadrowych pielęgniarek i położnych w Polsce, do roku 2020. Warszawa: Naczelna Izba Pielęgniarek i Położnych; 2010.

11. Naczelna Izba Pielęgniarek i Położnych. Analiza liczby zarejestrowanych i zatrudnionych pielęgniarek i położnych w roku 2011 oraz prognoza liczby zarejestrowanych i zatrudnionych pielęgniarek i położnych na lata 2015-2035. Warszawa: Naczelna Izba Pielęgniarek i Położnych; 2013.

12. Baumann A, Giovannetti P, O’Brien-Pallas L, Mallette C, Deber R, Blythe J, et al. Healthcare restructuring: The impact of job change. Can J Nurs Leadersh. 2001;14(1):14-20, https://doi.org/10.12927/cjnl.2001.16306.

13. Brooks BA, Anderson MA. Defining quality of nursing work life. Nurs Econ. 2005;23(6):319-26.

14. Ustawa z dnia 26 czerwca 1974 r. Labour Code 2017, item 129, 135-140, 143, 144.

15. Kilańska D, Gorzkowicz B, Sienkiewicz Z, Lewandowska M, Dominiak I, Bielecki W. Evaluation of chosen determinants of the positive practice environments (PPE) at Polish nursing wards. Med Pr. 2016;67(1):11-9, https:// doi.org/10.13075/mp.5893.00225.

16. Kilańska D. Środowisko pracy a poczucie satysfakcji zawodowej pielęgniarek - ekspozycja oczekiwań i wyobrażeń [doctoral dissertation]. Łódź: Medical University of Lodz; 2013.

17. Oriyama S, Miyakoshi Y, Kobayashi T. Effects of two 15-min naps on the subjective sleepiness, fatigue and heart rate variability of night shift nurses. Ind Health. 2014;52:25-35, https://doi.org/10.2486/indhealth.2013-0043.

18. Costa G, Sartori S. Flexible work hours, ageing and wellbeing. Chronobiol Int. 2004;21(6):831-44. 
19. Kosińska M, Kułagowska E, Szydło K, Trusz-Gluza M. Reakcje układu autonomicznego u pielęgniarek na sytuacje w pracy. Ann UMCS D. 2005;60(237 Suppl 16):54-8.

20. Hartenbaum N, Van Cauter E, Zee P. Shiftwork and sleep: Optimizing health, safety, and performance. J Occup Environ Med. 2011;53(5):1-10, https://doi.org/10.1097/JOM. 0b013e31821aec20.

21. Lewandowska A, Litwin B. Wypalenie zawodowe jako zagrożenie w pracy pielęgniarki. Pomeran J Life Sci. 2009; 55(3):86-9.

22. Richardson A, Turnock C, Harris L, Finley A, Carson S. A study examining the impact of 12-hour shifts on critical care staff. J Nurs Manag. 2007;15(8):838-46, https://doi. org/10.1111/j.1365-2934.2007.00767.x.

23. Anderson P, Townsend T. Medication errors: Don't let them happen to you. Am Nurs Today. 2010;5(3):23-8.

24. Townsend T, Anderson P. Are extended work hours worth the risk? Am Nurs Today. 2013;8(5):8-11.

25. Hänecke K, Tiedemann S, Nachreiner F, Grzech-Šukalo H. Accident risk as a function of hour at work and time of day as determined from accident data and exposure models for the German working population. Scand J Work Environ Health. 1998;24(3):43-8.

26. Merecz D, Mościcka A, Drabek M. Mobbing w środowisku pracy. Charakterystyka zjawiska, jego konsekwencje, aspekty prawne i sposoby przeciwdziałania. Łódź: Instytut Medycyny Pracy; 2005.

27. Lipińska M. Satysfakcja z pracy pielęgniarek i położnych. In: Materiały z III Konferencji Naukowej zorganizowanej w ramach programu „Rozwiązywanie problemów dla poprawy zdrowia”, Dreyfus Health Foundation „Ochrona Zdrowia Psychicznego Pielęgniarek i Położnych”; 2009 May 28-29; Katowice, Polska. Dreyfus Health Foundation; 2009.

28. Naczelna Izba Pielęgniarek i Położnych. Zabezpieczenie społeczeństwa polskiego w świadczenia pielęgniarek i położnych. Warszawa: Naczelna Izba Pielęgniarek i Położnych; 2015.

29. Hoffman AJ, Scott LD. Role stress and career satisfaction among registered nurses by work shift patterns. J Nurs Adm. 2003;33:337-42, https://doi.org/10.1097/00005110200306000-00006.

This work is available in an Open Access model and licensed under the Creative Commons Attribution-NonCommercial 3.0 Poland License - http:// creativecommons.org/licenses/by-nc/3.0/pl/deed.en. 